Preprint

UCRL-JC-141967

\title{
Manganin Gauge and Reactive Flow Modeling Study of the Shock Initiation of PBX 9501
}

\author{
C. M. Tarver, J. W. Forbes, F. Garcia, P. A. Untiew
}

This article was submitted to $12^{\text {th }}$ American Physical Society Topical Conference, Atlanta, GA., June 24-29, 2001

Lawrence

Livermore

National

Laboratory

\section{June 5, 2001}

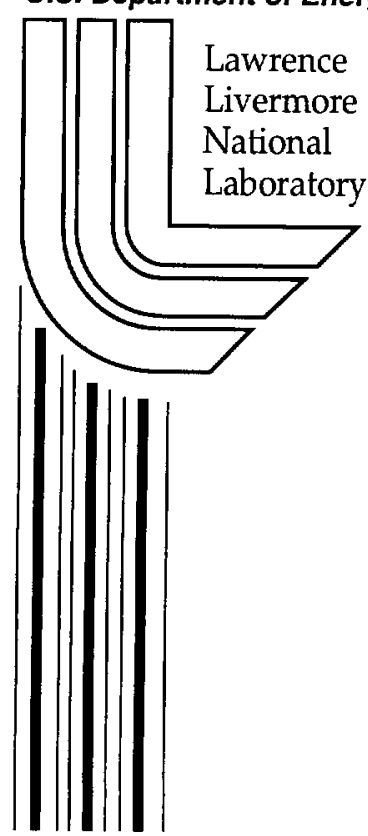




\section{DISCLAIMER}

This document was prepared as an account of work sponsored by an agency of the United States Government. Neither the United States Government nor the University of California nor any of their employees, makes any warranty, express or implied, or assumes any legal liability or responsibility for the accuracy, completeness, or usefulness of any information, apparatus, product, or process disclosed, or represents that its use would not infringe privately owned rights. Reference herein to any specific commercial product, process, or service by trade name, trademark, manufacturer, or otherwise, does not necessarily constitute or imply its endorsement, recommendation, or favoring by the United States Government or the University of California. The views and opinions of authors expressed herein do not necessarily state or reflect those of the United States Government or the University of California, and shall not be used for advertising or product endorsement purposes.

This is a preprint of a paper intended for publication in a journal or proceedings. Since changes may be made before publication, this preprint is made available with the understanding that it will not be cited or reproduced without the permission of the author.

This work was performed under the auspices of the United States Department of Energy by the University of California, Lawrence Livermore National Laboratory under contract No. W-7405-Eng-48.

This report has been reproduced directly from the best available copy.

Available electronically at http://www.doc.gov/bridge

Available for a processing fee to U.S. Department of Energy

And its contractors in paper from

U.S. Department of Energy

Office of Scientific and Technical Information

P.O. Box 62

Oak Ridge, TN 37831-0062

Telephone: (865) 576-8401

Facsimile: (865) 576-5728

E-mail: reports@adonis.osti.gov

Available for the sale to the public from

U.S. Department of Commerce

National Technical Information Service

5285 Port Royal Road

Springfield, VA 22161

Telephone: (800) 553-6847

Facsimile: (703) 605-6900

E-mail: orders@ntis.fedworld.gov

Online ordering: http://www.ntis.gov/ordering.htm

\section{OR}

Lawrence Livermore National Laboratory

Technical Information Department's Digital Library

http://www.llnl.gov/tid/Library.html 


\title{
MANGANIN GAUGE AND REACTIVE FLOW MODELING STUDY OF THE SHOCK INITIATION OF PBX 9501*
}

\author{
C. M. Tarver, J. W. Forbes, F. Garcia and P. A. Urtiew \\ Lawrence Livermore National Laboratory, \\ P.O. Box 808, L-282, Livermore, CA 94551
}

\begin{abstract}
A series of $101 \mathrm{~mm}$ diameter gas gun experiments was fired using manganin pressure gauges embedded in the HMX-based explosive PBX 9501 at initial temperatures of $20^{\circ} \mathrm{C}$ and $50^{\circ} \mathrm{C}$. Flyer plate impact velocities were chosen to produce impact pressure levels in PBX 9501 at which the growth of explosive reaction preceding detonation was measured on most of the gauges and detonation pressure profiles were recorded on some of the gauges placed deepest into the explosive targets. All measured pressure histories for initial temperatures of $25^{\circ} \mathrm{C}$ and $50^{\circ} \mathrm{C}$ were essentially identical. Measured run distances to detonation at several input shock pressures agreed with previous results. An existing ignition and growth reactive flow computer model for shock initiation and detonation of PBX 9501, which was developed based on LANL embedded particle velocity gauge data, was tested on these pressure gauge results. The agreement was excellent, indicating that the embedded pressure and particle velocity gauge techniques yielded consistent results.
\end{abstract}

\section{INTRODUCTION}

The relative safety of high energy materials based on octahydro-1,3,5,7-tetranitro-1,3,5,7-tetrazocine (HMX) is very important. PBX 9501, which contains 95 weight \% HMX, 2.5 weight \% estane binder, and 2.5 weight $\%$ BDNPA/F, is a widely used HMX-based plastic bonded explosive. Its shock sensitivity has previously been studied using embedded particle velocity gauges $(1,2)$ and VISAR at low input shock pressures $(3,4)$. In this paper, the shock sensitivity of $\mathrm{PBX} 9501$ at $25^{\circ} \mathrm{C}$ and $50^{\circ} \mathrm{C}$ was measured using embedded manganin pressure gauges to determine whether particle velocity measurement techniques agreed with pressure measurement techniques. The experimental records were compared through the use of the Ignition and Growth reactive flow model for PBX 9501, which had been previously normalized to particle velocity gauge data in the same input shock pressure regime (3). If this PBX 9501 Ignition and Growth model can calculate manganin pressure gauge records accurately with no adjustments, then the two experimental techniques are producing equilvalent shock initiation data. Thus they can be used interchangeably or in combination.

\section{EXPERIMENTAL}

The experimental geometry for the PBX 9501 embedded gauge experiments is identical to those in previous studies $(5-8)$. A $100 \mathrm{~mm}$ diameter, 12.5 mm thick aluminum flyer plate impacts a target consisting of: a $90 \mathrm{~mm}$ diameter, $6 \mathrm{~mm}$ thick aluminum plate; a $90 \mathrm{~mm}$ diameter, $20 \mathrm{~mm}$ thick PBX 9501 charge; and a $90 \mathrm{~mm}$ diameter, $6 \mathrm{~mm}$ thick aluminum back plate. In the heated experiments, the heaters were placed within the aluminum plates, and the PBX 9501 was heated to approximately $50^{\circ} \mathrm{C}$ at a rate of $1.6^{\circ} \mathrm{C} /$ minute. A total of three shots were fired. One $25^{\circ} \mathrm{C}$ experiment was fired with an aluminum flyer velocity of $0.697 \mathrm{~mm} / \mu$ s producing a shock pressure of approximately $3.2 \mathrm{GPa}$. Two shots were fired at $50^{\circ} \mathrm{C}$ with aluminum flyer plate velocities of 0.649 and $0.8005 \mathrm{~mm} / \mu \mathrm{s}$, imparting pressures of $3.1 \mathrm{GPa}$ and $4 \mathrm{GPa}$, respectively. An initial temperature of $50^{\circ} \mathrm{C}$ for PBX 9501 was used, because it is known that the shock sensitivity of HMX-based explosives increases for temperatures in the $150-170{ }^{\circ} \mathrm{C}$ regime (8), but no data was available in the $50^{\circ} \mathrm{C}$ range to which explosives may be subjected in hot climates and certain applications. 


\section{REACTIVE FLOW MODELING}

The Ignition and Growth reactive flow model uses two Jones-Wilkins-Lee (JWL) equations of state, one for the unreacted explosive and another one for the reaction products, in the temperature dependent form:

$$
p=A e^{-R_{1} V}+B e^{-R_{2} V}+\omega C_{v} T / V
$$

where $\mathbf{p}$ is pressure in Megabars, $\mathrm{V}$ is relative volume, $T$ is temperature, $\omega$ is the Gruneisen coefficient, $C_{V}$ is the average heat capacity, and $A, B$, $R_{1}$ and $R_{2}$ are constants. The unreacted equation of state is fitted to the available shock Hugoniot data, and the product equation of state is fitted to cylinder test and other metal acceleration data. The reaction rate equation is:

$$
\begin{aligned}
& d F / d t=I(1-F)^{b}\left(\rho / \rho_{o}-1-a\right)^{x}+G_{1}(1-F)^{c} F^{d} p^{y} \\
& 0<\mathrm{F}<\mathrm{F}_{\text {igmax }} \quad 0<\mathrm{F}<\mathrm{F}_{\text {GImax }} \\
& +\mathrm{G}_{2}(1-\mathrm{F})^{\mathrm{e}} \mathrm{Fg}^{\mathrm{g}} \mathrm{p}^{\mathrm{z}} \\
& \mathrm{F}_{\text {G2min }}<\mathrm{F}<1
\end{aligned}
$$

where $F$ is the fraction reacted, $t$ is time in $\mu s, p$ is the current density in $\mathrm{g} / \mathrm{cm}^{3}, \rho_{\mathrm{O}}$ is the initial density, $p$ is pressure in Mbars, and $I, G_{1}, G_{2}, a, b, c, d, e$, $\mathrm{g}, \mathrm{x}, \mathrm{y}$, and $\mathrm{z}$ are constants. This three term reaction rate law models the three stages of reaction generally observed during shock initiation of pressed solid explosives (6). The equation of state parameters for PBX 9501, aluminum, and Teflon, and the Ignition and Growth rate law parameters for PBX 9501 are listed in Table 1 . These parameters were previously normalized to several particle velocity gauge experiments fired at Los Alamos National Laboratory. Sheffield et al. (1) did a careful study of the effect of initial density on the shock sensitivity of new and aged PBX 9501. The average density of the three PBX 9501 charges used in this study was $1.838 \mathrm{~g} / \mathrm{cm}^{3}$. A change in temperature from $25^{\circ} \mathrm{C}$ to $50^{\circ} \mathrm{C}$ does not change the density significantly. The only change in the $50^{\circ} \mathrm{C}$ PBX 9501 parameters from the ambient parameters is a lower $B$ value in the unreacted JWL equation of state so that $p=0$ at $V=1$ and $\mathrm{T}_{\mathrm{o}}=323^{\circ} \mathrm{K}$.

TABLE 1. Equation of State and Reaction Rate Parameters

1. Ignition and Growth Model Parameters for PBX 9501

$\mathrm{T}_{\mathrm{o}}=298^{\circ} \mathrm{K} ; \rho_{\mathrm{o}}=1.838 \mathrm{~g} / \mathrm{cm}^{3} ;$ Shear Modulus $=0.0354$ Mbar; Yield Strength $=0.002 \mathrm{Mbar}$

Unreacted JWL

Product JWL

$\mathrm{A}=7320 \mathrm{Mbar}$

$A=16.689$ Mbar

$\mathrm{B}=-0.052654 \mathrm{Mbar}$

$\mathrm{B}=0.5969 \mathrm{Mbar}$

$\mathrm{R}_{1}=14.1$

$\mathrm{R}_{1}=5.9$

$\mathrm{R}_{2}=1.41$

$\mathrm{R}_{2}=2.1$

$I=1.4 \mathrm{e}+$
$\mathrm{a}=0.0$
$\mathrm{~b}=0.667$

Reaction Rate Parameters

$\omega=0.8867$

$\omega=0.45$

$\mathrm{x}=20.0$

$\mathrm{G}_{2}=400$

$\mathrm{C}_{\mathrm{v}}=2.7806 \mathrm{e}-5 \mathrm{Mbar} l^{\circ} \mathrm{K}$

$\mathrm{C}_{\mathrm{V}}=1.0 \mathrm{e}-5 \mathrm{Mbar} /{ }^{\circ} \mathrm{K}$

$\mathrm{G}_{1}=130$

$\mathrm{g}=1.0$

$\mathrm{y}=2.0$

$F_{\text {igmax }}=0.3$

$\mathrm{E}_{\mathrm{O}}=0.095 \mathrm{Mbar}$

$c=0.667, d=0.277$

$\mathrm{F}_{\mathrm{G} 1 \mathrm{max}}=0.5$

$\mathrm{To}=50^{\circ} \mathrm{C}=323^{\circ} \mathrm{K} \quad \mathrm{B}=-0.055179 \mathrm{Mbar}$

2. Gruneisen Parameters for Inert Materials

\begin{tabular}{llllllll}
\multicolumn{7}{c}{} & $\mathrm{p}=\rho_{\mathrm{o}} \mathrm{c}^{2} \mu\left[1+\left(1-\gamma_{\mathrm{o}} / 2\right) \mu-\mathrm{a} / 2 \mu^{2}\right] /\left[1-\left(\mathrm{S}_{1}-1\right) \mu-\mathrm{S}_{2} \mu^{2} /(\mu+1)-\mathrm{s}_{3} \mu^{3} /(\mu+1)^{2}\right]^{2}+\left(\gamma_{o}+\mathrm{a} \mu\right) \mathrm{E}$ \\
whert & $\rho_{\mathrm{o}}\left(\mathrm{g} / \mathrm{cm}^{3}\right)$ & $\mathrm{c}(\mathrm{mm} / \mu \mathrm{s})$ & $\mathrm{S}_{1}$ & $\mathrm{~S}_{2}$ & $\mathrm{~s}_{3}$ & $\gamma_{0}$ & $\mathrm{a}$ \\
6061-T6 Al & 2.703 & 5.24 & 1.4 & 0.0 & 0.0 & 1.97 & 0.48 \\
Teflon & 2.15 & 1.68 & 1.123 & 3.98 & -5.8 & 0.59 & 0.0 \\
\hline
\end{tabular}

TABLE 2. Experimental flyer velocities, impact pressures, and run distances to detonation

\begin{tabular}{llcll}
\hline Flyer Velocity & Impact Pressure & PBX 9501 Temperature & \multicolumn{2}{l}{ Experimental Run to Detonation Results } \\
$(\mathrm{mm} / \mu \mathrm{s})$ & $(\mathrm{GPa})$ & $(\mathrm{C})$ & Distance $(\mathrm{mm})$ & Time $(\mu \mathrm{s})$ \\
0.697 & 3.4 & 25 & 11 & 3.4 \\
0.649 & 3.0 & 50 & 13 & 4.3 \\
0.8005 & 4.0 & 50 & 8 & 2.4 \\
\hline
\end{tabular}




\section{EXPERIMENTAL RESULTS}

Table 2 contains the experimental flyer velocities, impact pressures, and run distances to detonation for the three PBX 9501 shots. Figure 1 shows the measured pressure histories at the six gauge locations $(0,5,7,9,12$, and $15 \mathrm{~mm})$ in $\mathrm{PBX} 9501$ at $25^{\circ} \mathrm{C}$ impacted by an aluminum flyer plate at 0.697 $\mathrm{mm} / \mu \mathrm{s}$. The gauge records and calculations show that this input shock pressure of $3.2 \mathrm{GPa}$ causes detonation to occur just before the $12 \mathrm{~mm}$ gauge depth. Two other comparisons for $50^{\circ} \mathrm{C}$ PBX 9501 are shown in Figs. 2 and 3. Figure 2 contains six gauge records at $0,5,10,12,14$, and $17 \mathrm{~mm}$ for the $0.649 \mathrm{~mm} / \mu \mathrm{s}$ aluminum flyer impact velocity experiment. The transition to detonation occurs between 12 and $14 \mathrm{~mm}$. Figure 3 contains the manganin gauge records at four depths $(0,3,7$, and $10 \mathrm{~mm}$ ) for the $50^{\circ} \mathrm{C}$ PBX 9501 shot which had an aluminum flyer velocity of $0.8005 \mathrm{~mm} / \mathrm{ms}$. The transition to detonation occurred just beyond the 7 $\mathrm{mm}$ deep gauge. For all three experiments, the run distances and times to detonation agree well with those measured by Sheffield et al. $(1,2)$.

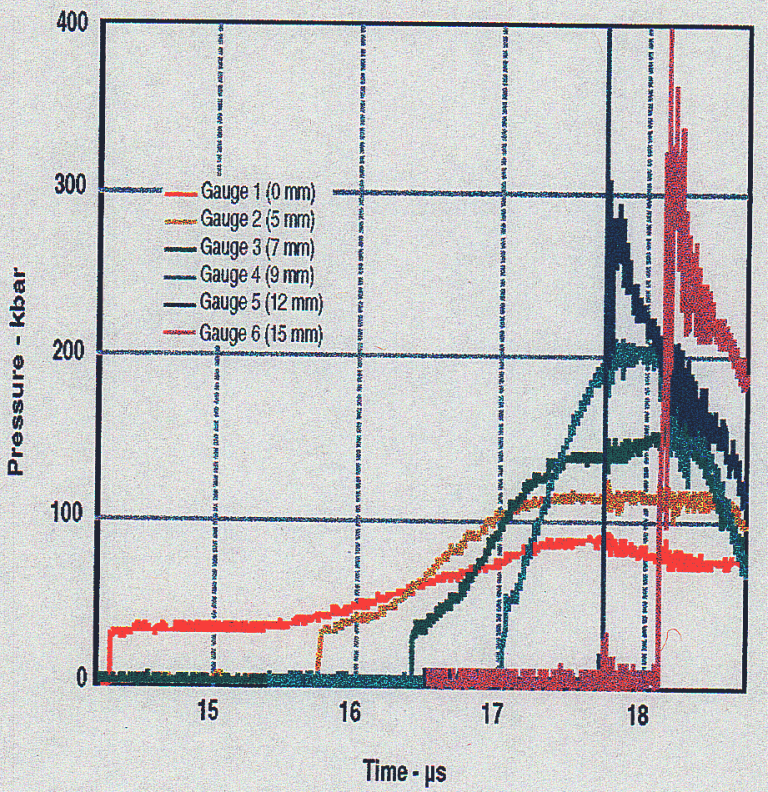

FIGURE 1. Pressure histories for $25^{\circ} \mathrm{C}$ PBX 9501 shock initiated by an aluminum flyer at $0.697 \mathrm{~mm} / \mu \mathrm{s}$

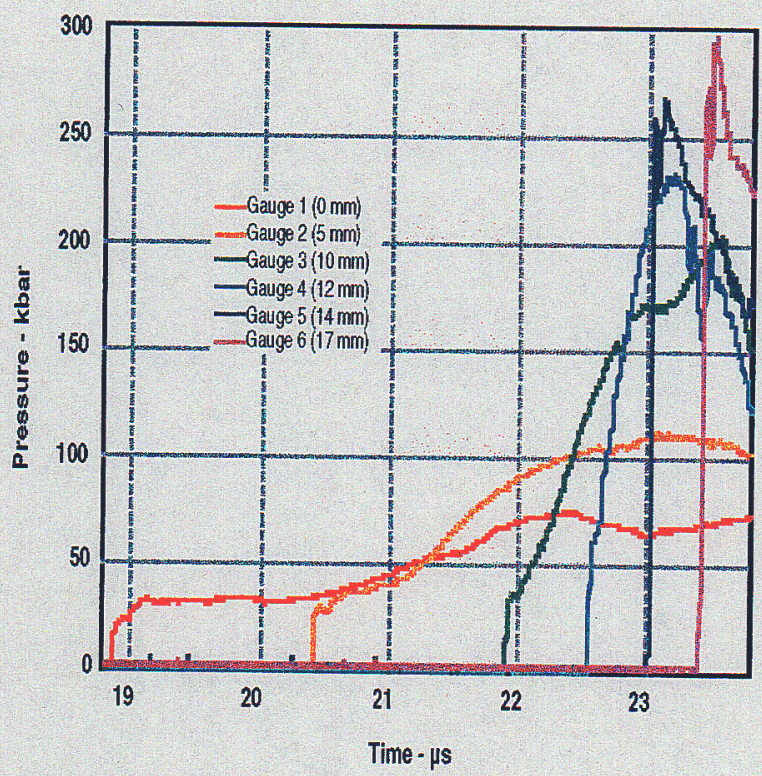

FIGURE 2. Pressure histories for $50^{\circ} \mathrm{C}$ PBX 9501 shock initiated by an aluminum flyer at $0.649 \mathrm{~mm} / \mu \mathrm{s}$

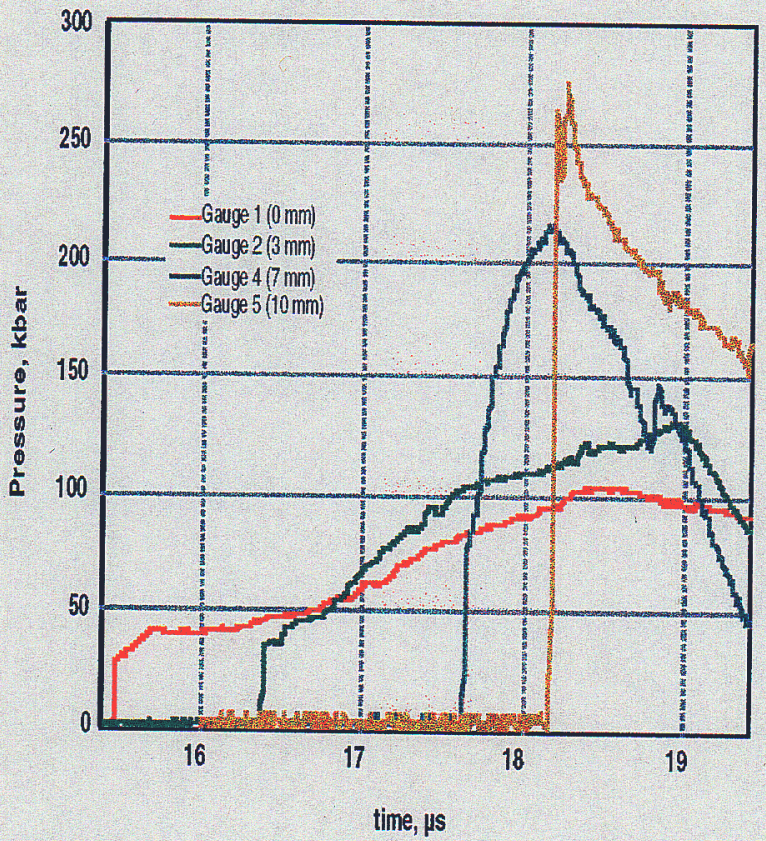

FIGURE 3. Pressure histories for $50^{\circ} \mathrm{C}$ PBX 9501 shock initiated by an aluminum flyer at $0.8005 \mathrm{~mm} / \mu \mathrm{s}$ 


\section{MODELING RESULTS}

The Ignition and Growth reactive flow modeling results for the three PBX 9501 experiments in Figs. 1 - 3 are shown in Figs. $4-6$, respectively. Ignition and Growth reactive flow modeling shows that manganin pressure gauges are yielding equilvalent results to particle velocity gauges.

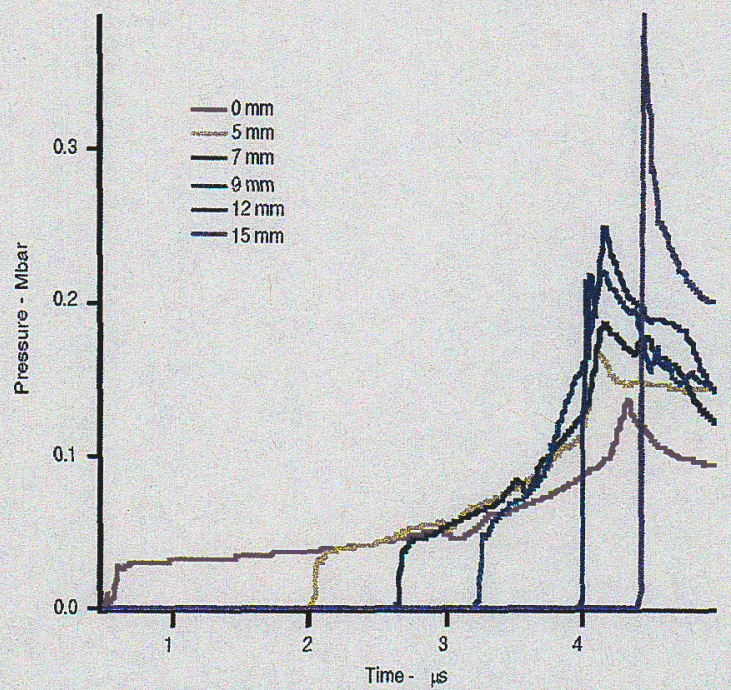

Figure 4. Calculated pressure histories for $25^{\circ} \mathrm{C}$ PBX 9501 impacted by an aluminum flyer at $0.697 \mathrm{~mm} / \mu \mathrm{s}$

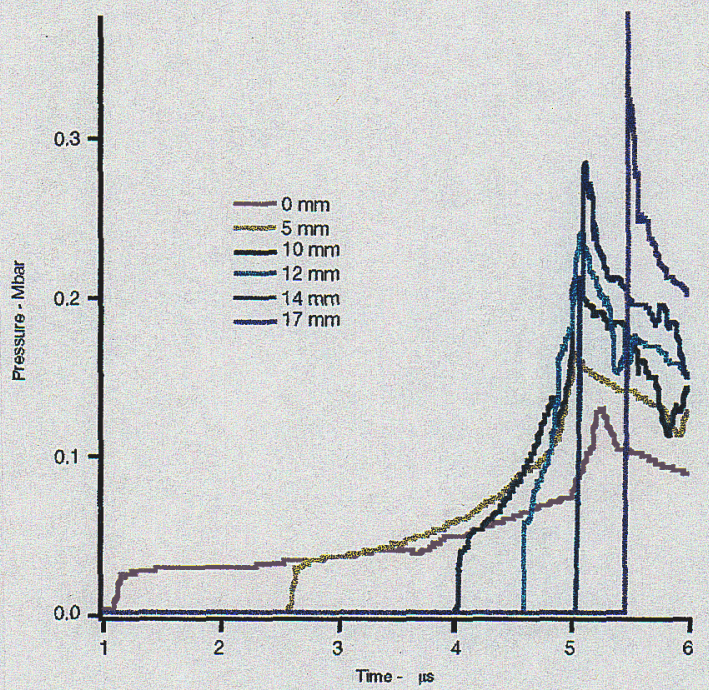

Figure 5. Calculated pressure histories for $50^{\circ} \mathrm{C}$ PBX 9501 impacted by an aluminum flyer at $0.649 \mathrm{~mm} / \mu \mathrm{s}$

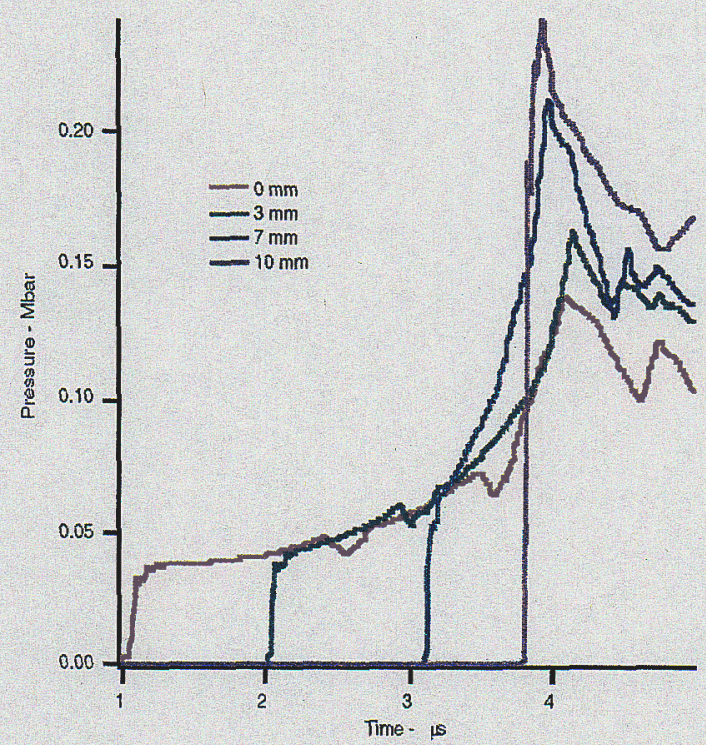

Figure 6. Calculated pressure histories for $50^{\circ} \mathrm{C}$ PBX 9501 impacted by an aluminum flyer at $0.8005 \mathrm{~mm} / \mu \mathrm{s}$

\section{ACKNOWLEDGMENTS}

This work was performed under the auspices of the U.S. Department of Energy by LLNL (contract number W-7405-ENG-48).

\section{REFERENCES}

1. Sheffield, S. A., Gustavsen, R. L., Hill, L. G., and Alcon, R R., Eleventh International Detonation Symposium, ONR 33300-5, Snommass, CO, 1998, pp. 451-458.

2. Sheffield, S. A., Gustavsen, R. L., and Alcon, R. R., Shock Compression of Condensed Matter-1999, M. D. Furnish, L. C Chhabildas, and R. S. Hixson, eds., AIP Conference Proceedings 505, Snowbird, UT, 1999, pp. 1043-1048.

3. Dick, J. J., Shock Compression of Condensed Matter-1999 M. D. Furnish, L. C. Chhabildas, and R. S. Hixson, eds , AIP Conference Proceedings 505, Snowbird, UT, 1999, pp. 683-686. 4. Dick, J, J., Martinez, A. R., and Hixson, R. S., Eleventh International Detonation Symposium, ONR 33300-5, Snommass, CO, 1998, pp. 317-324.

5. Urtiew, P. A., Tarver, C. M., Forbes, J. W., and Garcia, F., Shock Compression of Condensed Matter-1997, Schmidt, S. C., Dandekar, D. P., and Forbes, J. W., eds. AIP Press, New York, 1998, pp. 727-730.

6. Forbes, J. W., Tarver, C. M., Uritew, P. A., and Garcia, F., Eleventh International Detonation Symposium ONR 33300 5, Snommass, CO, 1998, pp. 145-152.

7. Tarver, C M. Forbes, J W Urtiew, PA and Garcia F Shock Compression of Condensed Matter-1999, Furnish, M. D. Chhabildas, L. C., and Hixson, R. S., eds., AIP Press, New York, 2000, pp. $891-894$

8. Urtiew, P. A., Forbes, J. W., Tarver, C., M., and Garcia, F. Shock Compression of Condensed Matter-1999, Furnish, M. D., Chhabildas, L. C., and Hixson, R. S., eds., AIP Press, New York, 2000, pp. 1019-1022 